\title{
POWOŁANIE I ODWOŁANIE PREZESA NARODOWEGO BANKU POLSKIEGO W KONSTYTUCJ RZECZYPOSPOLITEJ POLSKIEJ I USTAWIE O NARODOWYM BANKU POLSKIM
}

\begin{abstract}
WSTĘP
Przystępując do omawiania zagadnień związanych z powołaniem i odwołaniem Prezesa Narodowego Banku Polskiego (dalej Prezesa NBP), w pierwszej kolejności należy wskazać, że do tej pory regulacje odnoszące się do tej instytucji - czy to zawarte w Konstytucji ${ }^{1}$ czy też w ustawie o $\mathrm{NBP}^{2}$ (ale także w innych aktach prawnych) - nie były przedmiotem szerszego opracowania naukowego, pojawiały się jedynie przy okazji omawiania innych organów czy też instytucji związanych $z$ bankiem centralnym ${ }^{3}$. Nie jest to $w$ mojej ocenie wynikiem tego, że jest to organ o znaczeniu marginalnym, a wręcz przeciwnie - ostatnie lata wskazują na istotną rolę Prezesa NBP nie tylko w sferze działania banku centralnego, czy funkcjonowania rynku finansowego, ale także wspólpracy z władzą wykonawczą, ustawodawczą oraz przede wszystkim związaną z planami pełnego członkostwa Polski w Unii Walutowej i Gospodarczej (dalej UWG). Istniejący stan badań w zakresie instytucji Prezesa NBP jest zatem daleko niedostateczny, co przesądza o konieczności ich podjęcia. Wniosek taki jest uprawniony, tym bardziej że o coraz większej roli Prezesa NBP świadczy to, iż właśnie ten organ będzie odgrywał pierwszorzędną rolę w procesie pełnej integracji Polski w ramach trzeciego etapu

1 Konstytucja Rzeczypospolitej Polskiej z dnia 2 kwietnia 1997 r. (Dz.U. Nr 78, poz. 483 z późn. zm.)

2 Ustawa o Narodowym Banku Polskim z dnia 29 sierpnia 1997 r. (Dz.U. z 2005 r., Nr 1, poz. 2 z późn. zm. - tekst jedn.)

3 Wyjątkami w tym zakresie są publikacje M. Fedorowicz, Pozycja ustrojowa Prezesa Narodowego Banku Polskiego - zagadnienie wybrane, „Studia Lubuskie”2010, t. VI, s. 111 oraz S. Niemierki, Pozycja Prezesa NBP w ustawach bankowych, „Glosa” 1998, nr 8, s. 23.
\end{abstract}


integracji, tj. wprowadzenia w Polsce wspólnej waluty euro ${ }^{4}$. Natomiast już po przyjęciu euro i w ramach pełnego członkostwa w UWG to właśnie Prezes NBP będzie reprezentował interesy Polski w organach Europejskiego Banku Centralnego (dalej EBC).

Należy podkreślić, że stworzenie dobrych, kompleksowych i przejrzystych regulacji w zakresie powołania Prezesa NBP już na wstępie powinno doprowadzić do tego, że to jedno z najważniejszych stanowisk w systemie finansowym państwa będzie piastowała osoba dająca gwarancję wykonywania tej funkcji w sposób możliwie najlepszy we wszystkich płaszczyznach, gdzie przepisy prawa przewidują udział Prezesa NBP. Z kolei te same cechy w zakresie regulacji dotyczących odwołania Prezesa NBP winny dawać rękojmię, że w sytuacji, gdy zajdą przesłanki do jej zastosowania, proces ten będzie przebiegał szybko, bez konieczności oczekiwania na wykładnię niejasnych i niespójnych przepisów, jednocześnie zapewniając ciągłość prawidłowego funkcjonowania banku centralnego.

\section{POWOŁANIE PREZESA NARODOWEGO BANKU POLSKIEGO W KONSTYTUCJ}

W pierwszej kolejności należy wskazać, że ustrojodawca zaliczył Prezesa NBP do organów NBP (art. 227 ust. 2 Konstytucji) oraz uczynił go z mocy prawa Przewodniczącym Rady Polityki Pieniężnej (art. 227 ust. 5 Konstytucji). Te dwie instytucje tworzą pierwszą grupę zagadnień odnoszących się do Prezesa NBP. Warto podkreślić, iż w tym zakresie powyższe rozwiązanie podkreśla rolę nie tylko Prezesa NBP (jedyny organ monokratyczny NBP) w banku centralnym, ale także wśród dziesięcioosobowej Rady Polityki Pieniężnej (dalej RPP). Z punktu widzenia norm konstytucyjnych jest to trafne zasygnalizowanie roli, jaką ustrojodawca przewidział dla Prezesa NBP, z uwzględnieniem tego, że na podstawie art. 227 ust. 7 Konstytucji organizację i zasady działania Narodowego Banku Polskiego oraz szczegółowe zasady powoływania i odwoływania jego organów określi odrębna ustawa.

Drugą grupę rozwiązań Konstytucji w tym zakresie tworzą regulacje odnoszące się do trybu powołania Prezesa NBP (art. 227 ust. 3 Konstytucji) oraz negatywnych przeszkód wykluczających możliwość sprawowania tej funkcji (art. 227 ust. 4 Konstytucji). Nie ma moim zdaniem racjonalnego wytłumaczenia, że brak w Konstytucji równoczesnego wskazania (nie tylko w tej jednostce redakcyjnej,

\footnotetext{
$4 \quad$ Patrz szerzej, Raport na temat petnego uczestnictwa Rzeczypospolitej Polskiej w trzecim etapie Unii Walutowej i Gospodarczej, NBP, Warszawa 2009, oraz Raport Polska wobec perspektywy wstapienia do strefy euro za i przeciw szybkiej integracji walutowej, Warszawa 2008.
} 
ale w ogóle) trybu oraz organów mogących dokonać odwołania Prezesa NBP, mimo że takie rozwiązanie na podstawie art. 227 ust. 7 Konstytucji zostało wprowadzone do ustawy o NBP 5 , tym bardziej że odwołanie Prezesa NBP wedle ustawy o NBP jest procedurą analogiczną jak przy jego powołaniu, a w konsekwencji w tekście ustawy zasadniczej pozostaje jedynie kwestia „wzbogacenia” obowiązującej regulacji o dwa zwroty „i odwołuje”, co w żaden sposób nie prowadzi do zbytniej szczegółowości Konstytucji, a z pewnością zawierałoby kompleksowe uregulowanie tej kwestii. Jednocześnie warto w tym miejscu podkreślić, że to Prezydent został konstytucyjnie upoważniony do przedstawiania kandydata (tylko jednego ${ }^{6}$ na to stanowisko i w tym zakresie jest zobligowany do uzyskania aprobaty Sejmu ${ }^{7}$.W Konstytucji nie zawarto bardziej szczegółowych regulacji w tym zakresie, tj. w jakim terminie winno nastąpić zgłoszenie kandydata przez Prezydenta (w przypadku wygaśnięcia kadencji poprzednika) czy też dokonanie jego wyboru przez Sejm, słusznie zakładając, że tego rodzaju regulacje szczegółowe winny znaleźć swoje rozwinięcie w aktach niższego rzędu (co jednak nie nastąpiło) ${ }^{8}$. Równocześnie w zakresie długości trwania kadencji Prezesa NBP przyjęto rozwiązanie dotyczące innego okresu sprawowania tej funkcji niż kadencja Sejmu czy Prezydenta, co miało gwarantować i zapewniać jego niezależność. Ustrojodawca nie doprecyzował jednakże wprost w Konstytucji, że zwrot „powoływany na 6 lat” dotyczy instytucji „kadencji” Prezesa NBP, nie wspominając już o liczbie kadencji, jaką może sprawować ta sama osoba, a przecież w odniesieniu do osób stojących na czele innych instytucji publicznych konstytucyjnie określonych zawarto tego rodzaju rozwiązanie wprost w Konstytucji (np. art. 205 ust. 1 Konstytucji w zakresie Prezesa Najwyższej Izby Kontroli). W tym przypadku ten brak

$5 \quad$ Nie było tak jednak w uchwalonej 29 sierpnia 1997 r. ustawie o NBP, jej art. 9 ust. 1 miał bowiem identyczne brzmienie jak art. 227 ust. 3 Konstytucji, rodząc zupełnie niepotrzebne wątpliwości i rozbieżności do trybu i sposobu odwołania Prezesa NBP. Dopiero nowelizacja ustawy o NBP z dnia 18 grudnia 2003 r. o zmianie ustawy o Narodowym Banku Polskim oraz o zmianie innych ustaw (DzU Nr 228, poz. 2260) uzupełniła w niezbędnym zakresie „lukę prawną”, jaka na skutek przeoczenia ustawodawcy pojawiła się w zakresie instytucji Prezesa NBP i jego odwołania.

6 Obowiązujące zapisy Konstytucji RP oraz dotychczasowa praktyka wskazują, że tryb powołania Prezesa NBP odnosi się do jednej osoby, którą zawiera wniosek Prezydenta RP skierowany do Sejmu. Dopiero, gdy Sejm nie dokona jego powołania, Prezydent winien dokonać przedstawienia kolejnego, ale znowu tylko jednego kandydata na stanowisko Prezesa NBP. Obowiązujące przepisy Konstytucji wykluczają moim zdaniem możliwość, aby Prezydent w swoim wniosku wskazał np. dwóch kandydatów, spośród których Sejm dokonałby wyboru Prezesa NBP. Niezasadne wydaje się także w świetle obowiązujących regulacji ponowne zgłoszenie kandydata, którego już raz Sejm nie powołal.

7 Na podstawie art. 144 ust. 2 i 3 Konstytucji ten akt urzędowy Prezydenta Rzeczypospolitej nie wymaga dla swojej ważności podpisu Prezesa Rady Ministrów, który przez podpisanie aktu ponosi odpowiedzialność przed Sejmem.

8 Tak trafnie P. Winczorek, Prawo nie formutuje jasno wymogów zawodowych wobec Prezesa $N B P$, , Rzeczpospolita” z dnia 6-7 stycznia 2007, s. C3. 
został, co prawda doprecyzowany w ustawie o $\mathrm{NBP}^{9}$, ale nie do końca można zgodzić się, że ustawodawca w akcie niższym rangą, zawężając liczbę sprawowania kadencji Prezesa NBP przez tę samą osobę, miał podstawę prawną w zapisie art. 227 ust. 7 Konstytucji.

Trzecią grupę regulacji zawartych w Konstytucji, a odnoszących się do Prezesa NBP, tworzy przepis odsyłający w zakresie organizacji i zasad działania Narodowego Banku Polskiego oraz szczegółowych zasad powoływania i odwoływania jego organów do ustawy (art. 227 ust. 7 Konstytucji). W tym przypadku ustrojodawca, dbając zapewne o przejrzystość zwięzłość regulacji Konstytucji, wyraźnie wskazał na zakres przedmiotowy, jaki winien zostać uregulowany w ustawie, przy założeniu jego zgodności z Konstytucją.

Resumując, należy wskazać, że regulacje Konstytucji odnoszące się do powołania i odwołania Prezesa NBP, nawet bez zmian wynikających z procesu przyjęcia wspólnej waluty euro, już teraz wymagają doprecyzowania i poszerzenia. Będzie to fragment szerszego procesu, jaki zapewne nastąpi w odniesieniu do wszystkich rozwiązań zawartych w Konstytucji, a dotyczących banku centralnego, oraz w ustawie o NBP. Pomijając konieczność zmian w zakresie funkcji emisyjnej banku centralnego oraz prowadzenia polityki pieniężnej, a tym samym statusu RPP, konieczne będzie także ujęcie na nowo rozwiązań odnoszących się do zadań Prezesa NBP, zwłaszcza w perspektywie jego zwiększonej roli, jaką będzie odgrywał nie tylko w NBP, ale także w zakresie zewnętrznych relacji czy to w ramach struktur $\mathrm{EBC}^{10}$, czy też z krajowymi organami władzy wykonawczej i ustawodawczej. Wydaje się, że pełne i kompleksowe zapisy dotyczące jego powołania, ale także odwołania oraz liczby kadencji, jaką może wypełniać na tym stanowisku ta sama osoba, oraz ograniczenie w zakresie innej działalności winny mimo wszystko znaleźć się w Konstytucji celem zagwarantowania niezależności i podkreślenia roli Prezesa NBP. Niewykluczone jest także w regulacjach Konstytucji udzielenie Prezesowi NBP ochrony chociażby w postaci immunitetu formalnego o charakterze względnym.

9 Także w tym przypadku pierwotny tekst ustawy o NBP nie zawierał w ogóle odniesienia do instytucji „kadencji Prezesa NBP”, powtarzając dosłownie w art. 9 ust. 1 ustawy o NBP treść art. 227 ust. 3 Konstytucji, a w art. 9 ust. 2 wskazując jedynie, że „ta sama osoba nie może być Prezesem NBP dłużej niż przez dwie kolejne kadencje”. Dopiero nowelizacją z dnia 18 grudnia 2003 r. o zmianie ustawy o Narodowym Banku Polskim oraz o zmianie innych ustaw (DzU z 2003 Nr 228, poz. 2260) wprowadzono do art. 9 ust. 2 zd. 1 ustawy o NBP zapis: „Kadencja Prezesa NBP wynosi 6 lat”, doprecyzowując w tym zakresie regulacje Ustawy Zasadniczej, że użyte sformułowanie „na 6 lat" zawarte w art. 227 ust. 3 Konstytucji dotyczy kadencji Prezesa NBP.

10 M. Olszak, Prawne przygotowania do przyjęcia euro przez Polskę - zarys problemu, „Przegląd Ustawodawstwa Gospodarczego" 2010, nr 5, s. 2. 


\section{POWOŁANIE PREZESA NARODOWEGO BANKU POLSKIEGO W USTAWIE O NBP}

Regulacje zawarte w ustawie o NBP, a odnoszące się do zagadnień związanych z Prezesem NBP są niezwykle skromne, a dodatkowo niepełne, co już na wstępie moim zdaniem rodzi daleko idące skutki w zakresie funkcjonowania tego monokratycznego organu banku centralnego. Wniosek ten dotyczy regulacji, które w założeniu miały uzupełnić i dopełnić regulacje Konstytucji w zakresie wskazanym w art. 227 ust. 7 Konstytucji.

Należy podkreślić, że brak dla obowiązującego stanu prawodawstwa w tym zakresie racjonalnych przesłanek, zwłaszcza że Prezes NBP jest właśnie tym organem, który najczęściej jest utożsamiany nie tylko z rolą, jaką odgrywa bank centralny w systemie organów państwa, ale także w głównej mierze to właśnie Prezes NBP tworzy wizerunek banku centralnego i już w niedługim czasie odgrywać będzie pierwszoplanową rolę w procesie integracji i członkostwa w UWG. Stąd też należy na wstępie sformułować i przyjąć jako punkt wyjścia dla dalszych rozważań tezę, że regulacje ustrojowo-prawne dotyczące Prezesa NBP winny być kompleksowo uregulowane w materii ustawowej. Niestety aktualnie obowiązujące rozwiązanie w tym zakresie nie spełnia tych standardów, a wręcz przeciwnie - cechuje je wybiórczość, fragmentaryczność i niespójność, co w konsekwencji rodzi daleko idące, niekoniecznie pożądane skutki praktyczne w funkcjonowaniu tego organu banku centralnego.

Przenosząc powyższe rozważania na kanwę poszczególnych regulacji ustawy o NBP, w pierwszej kolejności należy wskazać, że doprecyzowania wymaga regulacja zawarta w art. 9 ust. 2 ustawy o NBP.

W tym zakresie ustawa doprecyzowuje zwrot zawarty w art. 227 ust. 3 Konstytucji, że powołanie na 6 lat dotyczy okresu kadencji Prezesa NBP, wskazując wprost, że kadencja Prezesa NBP wynosi 6 lat. Jednocześnie ustawa o NBP w dalszej części tej jednostki redakcyjnej doprecyzowuje, iż ta sama osoba nie może być Prezesem NBP dłużej niż przez dwie kolejne kadencje ${ }^{11}$.

Taka z pozoru prosta regulacja może w przyszłości budzić wątpliwości w wypadku, gdy ta sama osoba po pełnieniu przez dwie kolejne kadencje funkcji Prezesa NBP po upływie kadencji innej osoby ponownie starać się będzie o objęcie tego urzędu (na trzecią kadencję, ale nie kolejną tylko „przerwaną kadencją innej osoby"). Z literalnego brzmienia zapisu art. 9 ust. 2 ustawy o NBP wynika, że nie ma formalnie zakazu, aby taka osoba w takiej konfiguracji ponownie mogła

11 Zmiana art. 9 ust. 2 ustawy o NBP w tym zakresie wynika $\mathrm{z}$ ustawy z dnia 18 grudnia 2003 r. o zmianie ustawy o Narodowym Banku Polskim oraz o zmianie innych ustaw (DzU Nr 228, poz. 2260). Mimo wszystko nie rozwiązano w ten sposób wszystkich wątpliwości interpretacyjnych. 
się ubiegać o tę funkcję. Niemniej jednak należy moim zdaniem uznać, iż intencją ustawodawcy było raczej wyłączenie możliwości ubiegania się tej samej osoby o trzecią (nie kolejną) kadencję w sytuacji, gdy wcześniej pełniła tę funkcję przez dwie kadencje (w ogóle, a nie kolejne). Rozwiązaniem tej kwestii byłoby zawarcie w Konstytucji (choć nie można wykluczyć że w ustawie o NBP) zapisu, który wprost wskazywałby, że ta sama osoba może być ponownie powołana na Prezesa NBP tylko jeden raz. W ten sposób uniknie się wątpliwości, jakie rodzi obowiązująca regulacja.

O wiele bardziej znaczącym problemem w zakresie regulacji dotyczących powołania Prezesa NBP jest jednak to, że ustawa o NBP w ogóle nie zawiera zapisów odnoszących się do „osoby kandydata” na Prezesa NBP w zakresie jego kompetencji, doświadczenia, wykształcenia, obywatelstwa, uprzedniej karalności, znajomości języków obcych itd. W tym zakresie nie zawiera tych zagadnień Ustawa Zasadnicza, co jest raczej uzasadnione (prowadziłoby to niepotrzebnego rozbudowania regulacji Konstytucji), ale brak regulacji w tym zakresie w ustawie o NBP jest moim zdaniem ewidentnym przeoczeniem ustawodawcy. Oznacza to, że w aktualnym stanie prawnym każdy może zostać Prezesem NBP, o ile spełni przesłanki art. 9 ust. 1 ustawy o NBP (a więc zostanie zgłoszony przez Prezydenta RP i powołany przez Sejm). Takie rozwiązanie nie jest dobre ani właściwe nie tylko z punktu widzenia banku centralnego, ale całego systemu finansowego. Tego rodzaju zaniechanie ustawodawcy w tym zakresie, a więc istniejący brak ustawowej regulacji co do warunków, jakie winien spełniać kandydat na Prezesa NBP, osłabia nie tylko pozycję banku centralnego, ale także pozycję samego Prezesa NBP. W skrajnym przypadku przy braku regulacji w tym zakresie może dojść do sytuacji, gdy Prezes NBP powołany w trybie art. 9 ust. 1 ustawy o NBP jest osobą niemającą odpowiedniego wykształcenia np. ekonomicznego czy prawniczego, doświadczenia w bankowości, wieku oraz nie jest obywatelem polskim, a nawet nie włada językiem polskim ${ }^{12}$. Jest to oczywiście przykład, który może zaistnieć tylko i wyłącznie teoretycznie, ale nawet jako akademicki winien budzić uzasadnione reakcje na brak odpowiednich regulacji w tym zakresie $\mathrm{w}$ materii ustawowej. Idąc dalej i trzymając się koncepcji racjonalnego ustawodawcy, nietrudno wskazać na dalsze graniczące $\mathrm{z}$ absurdem sytuacje, w których ten sam ustawodawca stawia wysokie wymagania osobom, które ubiegają się o funkcje prezesa czy nawet członka zarządu banku komercyjnego (czy to spółki akcyjnej, czy banku spółdzielczego $)^{13}$, ale tych wysokich wymagań nie stawia przed osobą, która ubiega się o fotel Prezesa NBP - szefa banku centralnego. Innymi słowy

12 Tak trafnie, P. Winczorek, op. cit., s. C3.

13 W szczególności takie warunki kandydatom na prezesa zarządu stawia ustawodawca w art. 22 a, 22b oraz 30 ustawy z dnia 29 sierpnia 1997 r. - Prawo bankowe (DzU z 2002 r. Nr 72, poz. 665 z późn. zm. - tekst jedn.), a w przypadku banków spółdzielczych w art. 12 ustawy z dnia 7 grudnia 
osoba, która np. nie spełnia wedle regulacji ustawy o funkcjonowaniu banków spółdzielczych, ich zrzeszaniu się i bankach zrzeszających kryteriów do objęcia stanowiska np. prezesa zarządu w banku spółdzielczym i tym samym nie może zostać powołana do jego pełnienia, może zostać Prezesem NBP, albowiem prawo nie stawia wobec takiej osoby żadnych, nawet minimalnych, wymagań. Doprawdy brak racjonalnych powodów dla takiego rozwiązania, co nie zmienia faktu, że tak prezentuje się obecny stan polskich regulacji prawnych w tym zakresie. Należy zważyć, iż Prezes NBP, co do którego prawo nie stawia wymogów fachowości i wykształcenia, stoi na czele dwóch organów kolegialnych, w skład których wchodzą fachowcy i praktycy (zarząd NBP) oraz specjaliści z zakresu finansów (RPP), a nadto wchodzi w skład Komitetu Stabilności Finansowej ${ }^{14}$. Trudno sobie wyobrazić, aby w takim przypadku pozycja i rola Prezesa NBP były postrzegane jako mocne i dominujące, mimo że ustawodawca właśnie taki przymiot wiąże z piastowaniem funkcji Prezesa NBP.

Ustawodawca milczy także w zakresie karalności osoby ubiegającej się o funkcję Prezesa NBP, choć trudno przyjąć, aby taka osoba zyskała poparcie Sejmu czy Prezydenta niezbędne do powołania na szefa banku centralnego. Sytuacja jest stosunkowo prosta, gdy wyrok skazujący jest prawomocny już w fazie powoływania danej osoby na stanowisko Prezesa NBP, ale o wiele bardziej komplikuje się sytuacja, gdy zapadł wyrok warunkowo umarzający postępowanie albo gdy sprawa nie została jeszcze zakończona prawomocnym rozstrzygnięciem, a osoba ubiegająca się o stanowisko Prezesa NBP jest tylko oskarżona o dany czyn i nadal istnieje co do niej domniemanie niewinności zagwarantowane nie tylko w ustawie (art. $5 \$ 1 \mathrm{kpk}$ ), ale także w Konstytucji (art. 42 ust. 3). Także w tym przypadku „milczenie ustawodawcy”, niedające się pogodzić z doktryną jego racjonalności, może w przyszłości budzić daleko idące rozbieżności interpretacyjne. Ale tak zakreślony problem tylko z pozoru wydaje się koncentrować na orzeczeniu Sądu w zakresie rodzaju rozstrzygnięcia wydanego wobec osoby ubiegającej się o funkcję Prezesa NBP. Warto podkreślić, że sprawa zawisła przed sądem, a następnie wydany wyrok może dotyczyć wszelkiego rodzaju przestępstw - zarówno tych stypizowanych w kodeksie karnym, jak i w kodeksie karnym skarbowym, ściganych $\mathrm{z}$ urzędu oraz na wniosek i z oskarżenia prywatnego, wreszcie tych popełnionych umyślnie, jak i nieumyślnie oraz w celu osiągnięcia korzyści majątkowej lub osobistej oraz w związku $\mathrm{z}$ pełnioną funkcją. W tym zakresie ustawodawca nie dokonuje (wobec braku tych regulacji) w ustawie o NBP żadnego rozróżnienia, co moim zdaniem winno jednak nastąpić $z$ uwagi na niezwykle szeroko określoną

2000 r. o funkcjonowaniu banków spółdzielczych, ich zrzeszaniu się i bankach zrzeszających (DzU Nr 119, poz. 1252 z późn. zm.)

14 Patrz szerzej, P. Stanisławiszyn, Komitet Stabilności Finansowej, [w:] Bezpieczeństwo rynku finansowego, red. E. Fojcik-Mastalska, E. Rutkowska-Tomaszewska, Wrocław 2010, s. 83. 
przesłankę do odwołania Prezesa NBP ${ }^{15}$. Także przyjęcie, że sam fakt posiadania statusu oskarżonego czy też podejrzanego np. $z$ oskarżenia prywatnego nie może jeszcze sam w sobie stanowić przesłanki do uznania takiej osoby za niegodną bycia Prezesem NBP, zwłaszcza gdy zarzut wobec takiej osoby jest bezzasadny w perspektywie dowodów zebranych w toku postępowania sądowego. Byłby to bardzo prosty instrument, aby osoby wchodzące potencjalnie w krąg kandydatów na Prezesa NBP eliminować z niego przez złożenie prywatnego aktu oskarżenia. W związku z powyższym należy doprecyzować w materii ustawowej także ujemną przeszkodę dla osób, które będą ubiegać się o powołanie na Prezesa NBP. Dotyczyłoby to osób, co do których zapadł prawomocny wyrok skazujący bądź warunkowo umarzający postępowanie za umyślne przestępstwa określone w kodeksie karnym i karnoskarbowym, z wyłączeniem przestępstw ściganych z oskarżenia prywatnego i na wniosek ${ }^{16}$.

Resumując powyższe rozważania, należy podkreślić, że wskazane powyżej niepełne regulacje odnośnie do warunków, jakie ma spełniać kandydat powoływany na Prezesa NBP winny być przy najbliższych zmianach ustawy o NBP niezwłocznie uwzględnione i uzupełnione.

Dodatkowo wśród innych jeszcze istotnych wymogów, jakie winien spełniać kandydat na Prezesa NBP, należy wymienić korzystanie z pełni praw publicznych, posiadanie wyższego wykształcenia prawniczego lub ekonomicznego, posiadanie co najmniej trzyletniego stażu pracy na stanowiskach kierowniczych, ukończonych 35 lat, posiadanie nieposzlakowanej opinii dającej rękojmię prawidłowego wykonywania powierzonych zadań, odpowiedniej wiedzy w zakresie bankowości albo doświadczenia zawodowego uzyskanego w trakcie pracy naukowej, pracy w podmiotach wykonujących działalność na rynku bankowym, znajomości języka obcego, np. angielskiego ${ }^{17}$. Dopiero uwzględnienie tych wszystkich uwag w materii ustawowej pozwoli na uznanie, że ustawodawca w sposób prawidłowy zagwarantował, aby do pełnienia funkcji Prezesa NBP byli powoływania najlepsi

15 Przy takiej konstrukcji, jaka znajduje oparcie w obowiązujących przepisach, nietrudno wyobrazić sobie sytuację, gdy Prezes NBP zostaje skazany, np. z art. 177 §1 kk za przestępstwo powszechne związane $\mathrm{z}$ ruchem drogowym, które jest, co do zasady, popełnione nieumyślnie, bez jakiegokolwiek związku z piastowaną funkcją, ale w konsekwencji stanowi to podstawę do jego odwołania. Analogicznie można dookreślić sytuację, gdy przeciwko Prezesowi NBP wytoczona zostanie sprawa $\mathrm{z}$ oskarżenia prywatnego. Także $\mathrm{w}$ tym przypadku zakończenie sprawy wyrokiem skazującym powoduje, że aktualizuje się przesłanka do odwołania Prezesa NBP.

${ }_{16}$ Jest to zgodne $z$ przyjętym zapatrywaniem wyrażonym w wyroku Trybunału Konstytucyjnego z dnia 29 stycznia 2002 r., sygn. akt K 19/01, OTK - A z 2002 r., nr 1, poz. 1.

17 Jako wzór dla takiej regulacji może posłużyć art. 7 ustawy z dnia 21 lipca 2006 r. o nadzorze nad rynkiem finansowym (DzU Nr 157, poz. 1119, z późn. zm.) odnoszący się do warunków, jakie winien spełniać kandydat na Przewodniczącego Komisji Nadzoru Finansowego. Oznacza to, że ustawodawca o wiele większe wymagania stawia osobie ubiegającej się o stanowisko Przewodniczącego KNF niż Prezesa NBP, co nie jest rozwiązaniem do końca racjonalnie uzasadnionym. 
kandydaci, którzy nie tylko posiadają wiedzę i doświadczenie, ale też będą godnie reprezentować bank centralny w stosunkach zewnętrznych, w tym międzynarodowych ${ }^{18}$.

Ostatnie w zakresie zagadnień dotyczących powołania Prezesa NBP, które także nie zostało zawarte $\mathrm{w}$ materii ustawowej, to kwestia terminów, w jakich winno nastąpić powołanie następcy w przypadku wygaśnięcia kadencji Prezesa NBP. W ustawie brak wskazań co do terminów, w jakich Prezydent winien wystąpić z wnioskiem do Sejmu o powołanie określonej osoby na to stanowisko ani w jakim terminie Sejm winien dokonać aktu jego powołania. Prezydent i Sejm winni dążyć do tego, aby powołanie nowego Prezesa NBP i objęcie przez niego obowiązków nastąpiło w ciągu 7 do 14 dni od daty wygaśnięcia kadencji poprzednika ${ }^{19}$, tak by możliwie płynnie zapewnić zmianę i przekazanie wykonywania tej funkcji przez nową osobę bez ujemnych konsekwencji dla banku centralnego oraz uczestników systemu finansowego ${ }^{20}$.

\section{ODWOŁANIE PREZESA NARODOWEGO BANKU POLSKIEGO W USTAWIE O NBP}

Tak samo, jak w przypadku regulacji ustawowych dotyczących powołania Prezesa NBP, także regulacje odnoszące się do wygaśnięcia kadencji Prezesa NBP cechuje wybiorczość i fragmentaryczność, a co za tym idzie brak precyzji, co moim

18 Należy także wskazać, iż problem wyżej opisany w zakresie braku ustawowego określenia wymagań wobec osób powoływanych na Prezesa NBP nie istnieje tylko w aspekcie teoretycznym, gdyż właśnie brak tych regulacji oraz trybu ich weryfikowania w procesie wyłaniania kandydatów na Prezesa NBP jest przyczyną sprawy zawisłej przed Sądem Rejonowym w Poznaniu z oskarżenia prywatnego ówczesnego Prezesa NBP Sławomira Skrzypka (obecnie jego spadkobierców) przeciwko aktualnemu członkowi RPP.

19 Należy w tym miejscu podkreślić, że istnieje rozróżnienie czasowe pomiędzy powołaniem Prezesa NBP a objęciem przez niego obowiązków. Pomiędzy tymi dwoma aktami o charakterze konwencjonalnym istnieje okres, który winien być skrócony do minimum, a rozwiązaniem tego zagadnienia może być ustawowe wskazanie, że objęcie obowiązków przez Prezesa NBP winno nastąpić na tym samym albo kolejnym posiedzeniu Sejmu, nie dłużej jednak niż w terminie 14 dni od dnia jego powołania.

${ }_{20} \mathrm{~W}$ aktualnym stanie prawnym zagadnienie tzw. czasokresu zostało doprecyzowane w art. 9a ustawy o NBP, wedle którego po wygaśnięciu kadencji Prezesa NBP z przyczyny określonej w art. 9 ust. 4 pkt 1 ustawy o NBP Prezes NBP pełni obowiązki do czasu objęcia obowiązków przez nowego Prezesa NBP. Natomiast w myśl art. 9a ust. 2 ustawy o NBP po wygaśnięciu kadencji Prezesa NBP z przyczyn określonych w art. 9 ust. 4 pkt 2-4 wiceprezes NBP - pierwszy zastępca Prezesa NBP pełni obowiązki Prezesa NBP do czasu objęcia obowiązków przez nowego Prezesa NBP. Warto podkreślić, że nastąpiło to dopiero ustawą z dnia 21 maja 2010 r. o zmianie ustawy o Narodowym Banku Polskim (DzU Nr 109 poz. 709), której wprowadzenie budziło kontrowersje, por. opinie prawne druk sejmowy nr 3008, źródło strona internetowa www.sejm.pl. 
zdaniem rodzi konieczność ich dookreślenia. Dobrym kierunkiem było wprost zawarcie w nowelizacji w art. 9 ust. 1 ustawy o NBP trybu i organów, jakie biorą udział w odwołaniu Prezesa NBP ${ }^{21}$. Mimo to instytucja odwołania Prezesa NBP, a w szczególności jego cztery przesłanki (art. 9 ust. 5 pkt 1-3 ustawy o NBP) może budzić kontrowersje, których przy prawidłowej legislacji można by uniknać bądź też w znacznym stopniu wykluczyć istniejące wątpliwości i rozbieżności.

Zagadnieniem, które budzi wątpliwości natury prawnej jest dookreślenie przesłanek, w jakich może dojść do odwołania Prezesa NBP (art. 9 ust. 5 ustawy o NBP). W materii ustawowej przesądzono, iż niezależnieod tego, jakie przesłanki w danym przypadku zaistnieją, odwołanie ma charakter fakultatywny, a więc od woli organów, które biorą udział w procedurze odwołania (Prezydent i Sejm), zależy, czy procedura taka zostanie zainicjowana i zostanie skutecznie przeprowadzona. Po analizie przesłanek odwołania Prezesa NBP wydaje się, że właściwsze byłoby w tym przypadku dokonanie ich podziału na fakultatywne, do których należałoby zaliczyć niewypełnianie obowiązków na skutek długotrwałej choroby (pkt 1), oraz obligatoryjne, do których należały pozostałe trzy przesłanki (pkt 2-3). Za takim rozróżnieniem przemawia fakt, że trudno sobie wyobrazić (choć w aktualnym stanie prawnym jest to możliwe), aby Prezes NBP skazany prawomocnym wyrokiem Sądu mógł nadal piastować swoje stanowisko tylko dlatego, że ustawodawca w tym zakresie przewidział fakultatywną formę jego odwołania. Byłoby to niewłaściwie nie tylko z punktu widzenia idei praworządności, ale wizerunku tak Prezesa NBP, jak i banku centralnego. Podobne argumenty należy podnieść w zakresie pozostałych przesłanek odwołania, tj. prawomocnego orzeczenia stwierdzającego, że złożył on niezgodne z prawdą oświadczenie lustracyjne, oraz orzeczenia Trybunału Stanu, który orzekł zakaz zajmowania kierowniczych stanowisk lub pełnienia funkcji związanych ze szczególną odpowiedzialnością w organach państwowych. W tym zakresie, gdy tego rodzaju rozstrzygnięcia zostaną wydane, nie tylko odwołanie winno mieć charakter obligatoryjny, ale dodatkowo powinno zostać obwarowane terminem, kiedy winno to nastąpić, ale rozważenia wymaga, czy zaistnienie tych przesłanek nie powinno z mocy prawa pociągać za sobą wygaśnięcia kadencji Prezesa NBP, bez konieczności potwierdzenia tego w drodze odrębnego postępowania, jakim jest procedura odwołania Prezesa NBP.

Wśród podstaw mogących prowadzić do odwołania Prezesa NBP na uwagę zasługuje pierwsza $\mathrm{z}$ nich, wskazująca, że nie wypełnia swoich obowiązków na skutek długotrwałej choroby (art. 9 ust. 5 pkt 1 ustawy o NBP). Zawarcie takiego rozwiązania przez posłużenie się zwrotem niedookreślonym (nawet w naukach medycznych) bez jego doprecyzowania o element dopełniający, np. czasu jej trwa-

21 Uczyniono to nowelizacją z dnia 18 grudnia 2003 r. o zmianie ustawy o Narodowym Banku Polskim oraz o zmianie innych ustaw ( $\mathrm{DzU}$ Nr 228, poz. 2260). 
nia, nie jest dobre, albowiem nie zawarto rozwiązań szczegółowo odnoszących się do tej przesłanki. Nie dookreślono, jak długo ma trwać ta choroba oraz kto ewentualnie, tj. jaki organ i w jakim trybie, ma stwierdzić owe niewypełnienie obowiązków przez Prezesa NBP na skutek długotrwałej choroby. Wydaje się, że posłużenie się klauzulą generalną w zakresie tej przesłanki odwołania Prezesa NBP nie było właściwym rozwiązaniem, tym bardziej że jest to kryterium niezwykle ocenne i obiektywnie trudno weryfikowalne. Wydaje się, że właściwsze byłoby stworzenie pewnego sztywnego horyzontu czasowego, np. okresu 6 miesięcy $^{22}$, w którym Prezes NBP nie wypełnia swoich obowiązków wskutek tejże choroby ${ }^{23}$. W tym zakresie warto jedynie wskazać, że ustawodawca nie posłużył się jako przesłanką oceny choroby stanem trwałego niewypełniania obowiązków przez Prezesa NBP, a więc należy przyjąć, iż skutkiem długotrwałej choroby ma być nie trwałe, ale całkowite, zupełne wyłączenie danej osoby od wykonywania obowiązków Prezesa NBP. Moim zdaniem dotyczy to sytuacji, w której dana osoba w danym momencie nie jest w stanie samodzielnie nie tyle brać udziału w posiedzeniach organów kolegialnych, co przede wszystkim rozeznać materii, którą się zajmuje. Tym samym dotyczy to Prezesa NBP nie tylko jako osoby stojącej na czele organów kolegialnych, ale wszystkich kompetencji, jakie dotyczą także Prezesa jako organu monokratycznego ${ }^{24}$.

Kolejną przesłanką odwołania Prezesa NBP jest skazanie prawomocnym wyrokiem sądu za popełnione przestępstwo. Tego rodzaju zapis pozwala na stwierdzenie, że dotyczy to wszelkich rodzaju przestępstw, nawet tych niemających związku z pełnioną funkcją, ale także tych, które zostały popełnione przed po-

22 W zakresie analogicznej regulacji odnoszącej się do Przewodniczącego KNF ustawodawca w art. 8 ust. 1 pkt 4 ustawy o nadzorze nad rynkiem finansowym wskazał, że następuje jego obligatoryjne odwołanie na skutek utraty zdolności do pełnienia powierzonych obowiązków w wyniku długotrwałej choroby, trwającej dłużej niż 3 miesiące.

${ }_{23} \mathrm{Na}$ marginesie jedynie należy wskazać, iż do podobnego stanu w zakresie przesłanki odwołania członka RPP ustawodawca użył innego sformułowania: „choroba trwale uniemożliwiająca sprawowanie funkcji”, choć niewątpliwie przyczyna i skutek zaistnienia danej przesłanki są identyczne jak w przypadku Prezesa NBP. Otwarte pozostaje pytanie, dlaczego racjonalny ustawodawca posługuje się w tym samym akcie prawnym i w tym samym zakresie dwoma różnymi pojęciami dla określenia takiego samego stanu faktycznego i jego skutków.

24 Ponadto innym zagadnieniem jest, który organ i w jakim trybie ma dokonać stwierdzenia, czy choroba ta ma charakter długotrwały, mając na uwadze, że w aspekcie medycznym jest to pojęcie względne, które jest odnoszone do konkretnej osoby w konkretnym momencie. O ile może być to zawsze ocena podana w wątpliwość, nie wiadomo jak należy postąpić, gdy osoba zainteresowana, tj. Prezes NBP, nie zgadza się z opinią odnośnie do zdrowia na swój temat. Czy przysługuje jej środek odwoławczy, ewentualnie, jeśli tak, to jaki i kto miałby to zagadnienie rozstrzygać. Nie można także wykluczyć sytuacji, że Prezes NBP, u którego wystąpi choroba długotrwałe uniemożliwiająca wypełnianie swoich obowiązków, zostanie jej pozbawiony, a następnie jego stan poprawi się o tyle, że nie ma przeszkód, aby sprawował ową funkcję. Wydaje się, że w takim przypadku brak jakichkolwiek środków prawnych, aby „przywrócić” taką osobę do wykonywania funkcji Prezesa NBP. 
wołaniem danej osoby na stanowisko Prezesa NBP, a np. ujawnionych i ściganych po objęciu przez taką osobę funkcji Prezesa NBP. Ustawa o NBP nie przewiduje w takiej sytuacji instytucji zawieszenia w czynnościach Prezesa NBP czy też nie nakłada na niego obowiązku złożenia rezygnacji (w sytuacji, gdy postępowanie karne znajduje się w fazie in personam albo sformułowano akt oskarżenia). Dopiero prawomocne orzeczenie sądu w tym zakresie i to w formie wyroku skazującego jest jedynie fakultatywną przesłanką do odwołania Prezesa NBP.

Oczywiste jest, że taka sytuacja nie będzie dobrze wpływała na wizerunek Prezesa NBP i banku centralnego. Stąd postulować należy zmianę tego zapisu poprzez przyjęcie, że przesłanka odwołania Prezesa NBP ma charakter obligatoryjny albo z mocy prawa - gdy zapadł prawomocny wyrok skazujący za popełnione przestępstwo, albo warunkowo umarzający postępowanie, $\mathrm{z}$ wyłączeniem przestępstw nieumyślnych i ściganych z oskarżenia prywatnego oraz na wniosek. Można także wskazać, że problem powyższy wyeliminowałoby zagwarantowanie ochrony Prezesowi NBP w postaci immunitetu formalnego, a tym samym na czas pełnienia funkcji Prezesa NBP żadne postępowanie karne nie mogłoby się toczyć ani zostać wszczęte z uwagi na ujemną przesłankę procesową, do czasu jej uchyle$\mathrm{nia}^{25}$, co dałoby efekt większej gwarancji i niezależności Prezesa NBP.

Podobne rozwiązanie $\mathrm{w}$ zakresie obligatoryjnej, a nie fakultatywnej przesłanki odwołania Prezesa NBP winno być zastosowane w sytuacji, gdy złożył on niezgodne z prawdą oświadczenie lustracyjne, stwierdzone prawomocnym orzeczeniem sądu. W tym przypadku nawet ochrona w postaci immunitetu nie stanowiłaby przeszkody do prowadzenia przez sąd postępowania w tym zakresie, a doprecyzowania wymagałoby jedynie to, że organ w tym przypadku odwołuje Prezesa NBP, przez zakreślenie terminu do wykonania tej czynności. Podobne rozwiązanie winno być zastosowane w odniesieniu do czwartej przesłanki odwołania Prezesa NBP w sytuacji, gdy Trybunał Stanu orzekł wobec niego zakaz zajmowania kierowniczych stanowisk lub pełnienia funkcji związanych ze szczególną odpowiedzialnością w organach państwowych.

Resumując, należy wskazać, że przesłanki odwołania Prezesa NBP zawarte w ustawie o NBP wymagają doprecyzowania i usystematyzowania przy najbliższej nowelizacji tej ustawy albo ujęcia ich na nowo w przypadku prac nad nowym aktem prawnym w tym zakresie. Uporządkowanie tej materii jest pożądane, aby w takich sytuacjach jasno można było określić nie tylko czy i jaki organ ma do-

25 Przyjęcie takiej konstrukcji oznaczałoby, że Prezes NBP nie mógłby być bez uprzedniej zgody np. Sejmu pociągnięty do odpowiedzialności karnej ani pozbawiony wolności. Także w tym przypadku Prezesa NBP nie można by było zatrzymać lub aresztować, z wyjątkiem sytuacji ujęcia go na gorącym uczynku przestępstwa i jeżeli jego zatrzymanie byłoby niezbędne do zapewnienia prawidłowego toku postępowania. O zatrzymaniu niezwłocznie powiadamiałoby się np. marszałka Sejmu, który mógłby nakazać natychmiastowe zwolnienie zatrzymanego. 
konać odwołania Prezesa NBP, ale przede wszystkim w jakim terminie winno to nastąpić, a to $z$ kolei jest powiązane $z$ powołaniem jego następcy ${ }^{26}$. Przy tym naczelną zasadą winno być zapewnienie prawidłowego funkcjonowania banku centralnego, co bezpośrednio jest związane z osobą Prezesa NBP ${ }^{27}$.

\section{ZAKOŃCZENIE}

Wskazane powyżej wybrane rozwiązania ustrojowoprawne dotyczące Prezesa NBP w zakresie jego powołania i odwołania, jako najbardziej charakterystyczne w zakresie obszaru prawnego regulującego funkcjonowanie tego organu, niewątpliwie pobudzają do refleksji nad zakresem i kierunkami zmian. Jest to istotne z punktu widzenia zadań i roli, jaką odgrywa Prezes NBP nie tylko w samym banku centralnym, ale $\mathrm{w}$ gospodarce czy może szerzej systemie finansowym, przede wszystkim w kontekście nadchodzących zmian w związku z przygotowaniem Polski do wejścia do Eurosystemu.

Bezsporne jest, że istniejąca w tym zakresie regulacja Konstytucji RP i ustawy o NBP, dotycząca Prezesa NBP w przedmiocie jego powołania i odwołania, oraz wykształcona praktyka nie są wystarczające dla zapewnienia przejrzystości $\mathrm{w}$ funkcjonowaniu banku centralnego. Także pozostawienie $\mathrm{w}$ aktualnym brzmieniu regulacji prawnych i odwołanie się do poglądów piśmiennictwa oraz praktyki nie jest zadowalającym i właściwym rozwiązaniem zwłaszcza w kontekście członkostwa w UWG i wynikających z tego zmian w strukturze i celach, zadaniach NBP.

Ogólną konkluzją jest konieczność kompleksowej i przemyślanej zmiany Konstytucji i ustawy o NBP w tym zakresie, którą należy przeprowadzić łącznie ze zmianami w prawodawstwa w kontekście członkostwa Polski w Unii Walutowej i Gospodarczej, tak by do minimum ograniczyć późniejsze interwencje ustawodawcy w regulacje odnoszące się do banku centralnego ${ }^{28}$.

Pozostawiając jednak w tym miejscu na boku rozważania $\mathrm{w}$ zakresie konieczności ich zmiany i dostosowania w przypadku pełnego członkostwa Polski

26 Warto wskazać, że powyższa uwaga dotyczy nie tylko procedury odwołania Prezesa NBP, ale także do innych przypadków wygaśnięcia kadencji Prezesa NBP, np. przez złożenie rezygnacji. Nie wskazano, w jakiej formie i trybie oraz któremu organowi winna być złożona rezygnacja Prezesa NBP, patrz szerzej pismo NBP z dnia 21.02.2011 r. GP-WP-PK/055/98/2011, patrz także M. Zubik, Narodowy Bank Polski (analiza konstytucyjno-ustrojowa), „Państwo i Prawo”, 2001, z. 6, s. 41, a także Sprawozdanie stenograficzne z obrad Sejmu w dniach 20-22 grudnia 2000 r., www.sejm.pl.

27 C. Kosikowski, Pozycja Narodowego Banku Polskiego i jego organów w prawie polskim, „Państwo i Prawo" 2002, z. 11, s. 14 i n.; P. Dziekański, Ustrojowa pozycja banku centralnego w Polsce, „Przegląd Prawa Publicznego" 2008, nr 9, s. 77.

${ }_{28}$ M. Fedorowicz, op. cit., s. 122. 
w UWG, warto podkreślić, że rozwiązania zawarte w Konstytucji odnoszące się do powołania i odwołania Prezesa NBP nie oddają w pełni roli i znaczenia osoby stojącej na czele banku centralnego. Niwelując ten problem, należałoby w Konstytucji zawrzeć regulacje odnośnie do trybu odwołania Prezesa oraz dookreślić, ile razy ta sama osoba może być powołana do pełnienia tej funkcji (jak to jest w art. 205 ust. 1 Konstytucji w odniesieniu do Prezesa NIK). Niewykluczone byłoby także dopełnienie regulacji Konstytucji odnośnie do dodatkowych przeszkód, jakie odnoszą się do osoby Prezesa NBP (art. 227 ust. 4 Konstytucji) przez doprecyzowanie wprost, że Prezes NBP nie może zajmować innego stanowiska, z wyją̧tkiem stanowiska profesora szkoły wyższej, ani wykonywać innych zajęć zawodowych. Ustrojodawca nie przewidział dla Prezesa NBP skorzystania $z$ instytucji immunitetu formalnego, który przysługuje takim organom jak Prezes Najwyższej Izby Kontroli (art. 206 Konstytucji) czy też Rzecznik Praw Obywatelskich (art. 211 Konstytucji). Ze względu na rosnące znaczenie i rolę Prezesa NBP trzeba, aby tego rodzaju ochrona w regulacjach Konstytucji została mu jednak przyznana i w tym zakresie należy zrównać jego status z innymi konstytucyjnie wyróżnionymi organami i podmiotami.

Niezależnie od tego w zakresie regulacji odnoszących się do Prezesa NBP, a zawartych w ustawie o NBP należy przede wszystkim doprecyzować instytucje uregulowane aktualnie w obowiązującym art. 9 ustawy o NBP oraz dokonać ich niezbędnego rozszerzenia. Regulacje odnośnie do Prezesa NBP winny zostać poszerzone o ustawowo określone warunki, jakie musi spełniać osoba ubiegająca się o to stanowisko. Dotyczyłoby nie tylko posiadania odpowiedniego wykształcenia, ale także wieku, doświadczenia oraz innych elementów (np. znajomości języka obcego, obywatelstwa, braku uprzedniej karalności), niezbędnych do prawidłowego wykonywania tej funkcji.

Zmiany w prawodawstwie winny także dotyczyć szerokiej grupy zagadnień, jaką są przesłanki odwołania Prezesa NBP. W ustawie winno się dokonać ich podziału na obligatoryjne i fakultatywne, doprecyzowując bądź też na nowo określając przesłankę odwołania związaną ze stanem zdrowia przez wskazanie wprost w ustawie charakteru i okresu choroby, jaki musi upłynąć, aby można było odwołać Prezesa NBP. W zakresie drugiej przesłanki odwołania Prezesa NBP, tj. skazania prawomocnym wyrokiem sądu za popełnione przestępstwo, należy je doprecyzować przez dookreślenie, że dotyczy to wyłącznie przestępstw umyślnych $\mathrm{z}$ wyłączeniem tych ściganych $\mathrm{z}$ oskarżenia prywatnego i na wniosek. Jako przesłanka odwołania winno także być uznane orzeczenie wobec Prezesa NBP przez sąd warunkowego umorzenia postępowania o czyn stanowiący przestępstwo umyślne ścigane $\mathrm{z}$ urzędu.

Alternatywą dla powyższych wymagań byłoby przyznanie wprost w zakresie statusu Prezesa NBP immunitetu formalnego w zakresie związanym z wykonywaniem tej funkcji. 
Wskazane powyżej propozycje dotyczące zmian w zakresie rozwiązań ustrojowych zawartych w ustawie o NBP nie wyczerpują całego zagadnienia dotyczącego „obszarów” funkcjonowania Prezesa NBP jako organu banku centralnego, które winny być postrzegane jako wymagające interwencji ustawodawcy. Należy przy ich podejmowaniu mieć na uwadze, iż jest to organ banku centralnego, ale jednocześnie instytucja, która nie tylko integruje i koordynuje prace banku centralnego, ale jest też istotnym ogniwem współpracy na szeroko rozumianym rynku finansowym na zewnątrz banku centralnego. Warto wskazać, że Prezes NBP jest członkiem Komisji Nadzoru Finansowego, Komitetu Stabilności Finansowej, by uzmysłowić sobie, że to, kto piastuje tę funkcję ${ }^{29}$, nie jest tylko wewnętrzną sprawą NBP, ale całego rynku finansowego. Skoro dążeniem uczestników rynku finansowego są organy i podmioty współpracujące ze sobą w celu integracji i realizacji określonych celów, to warunkiem wstępnym jest, aby na czele tych najważniejszych instytucji stały osoby pochodzące nie tylko z politycznego nadania, ale również przygotowane merytorycznie do wykonywania określonych zadań i działań.

\section{BIBLIOGRAFIA}

Dziekański P., Ustrojowa pozycja banku centralnego w Polsce, „Przegląd Prawa Publicznego” 2008, nr 9.

Fedorowicz M., Pozycja ustrojowa Prezesa Narodowego Banku Polskiego - zagadnienia wybrane, „Studia Lubuskie” 2010, t. VI.

Kosikowski C., Pozycja Narodowego Banku Polskiego i jego organów w prawie polskim, „Państwo i Prawo" 2002, z. 11.

Niemierka S., Pozycja Prezesa NBP w ustawach bankowych, „Glosa” 1998, nr 8.

Olszak M., Prawne przygotowania do przyjecia Euro przez Polske - zarys problemu, „Przegląd Ustawodawstwa Gospodarczego" 2010, nr 5.

Raport na temat petnego uczestnictwa Rzeczypospolitej Polskiej w trzecim etapie Unii Walutowej $i$ Gospodarczej, NBP, Warszawa 2009.

Raport Polska wobec perspektywy wstapienia do strefy Euro za i przeciw szybkiej integracji walutowej, Warszawa 2008.

Sotomska-Krzysztofik P., Szczepańska O., Przejrzystość banków centralnych we wspieraniu stabilności finansowej, „Bank i Kredyt” 2006, nr 11-12.

Sprawozdanie stenograficzne z obrad Sejmu w dniach 20-22 grudnia 2000 r.

Stanisławiszyn P., Komitet Stabilności Finansowej, [w:] Bezpieczeństwo rynku finansowego, red. E. FojcikMastalska, E. Rutkowska-Tomaszewska, Wrocław 2010.

29 Patrz szerzej O. Szczepańska, Rola banku centralnego w sieci bezpieczeństwa finansowego, „Bezpieczny Bank” 2007, nr 2-3, s. 65 oraz P. Sotomska-Krzysztofik, O. Szczepańska, Przejrzystość banków centralnych we wspieraniu stabilności finansowej, „Bank i Kredyt” 2006, nr 11-12, s. 44. 
Szczepańska O., Rola banku centralnego w sieci bezpieczeństwa finansowego, „Bezpieczny Bank" 2007, nr 2-3.

Winczorek P., Prawo nie formutuje jasno wymogów zawodowych wobec Prezesa NBP, „Rzeczpospolita” z dnia 6-7 stycznia $2007 \mathrm{r}$.

Zubik M., Narodowy Bank Polski (analiza konstytucyjno-ustrojowa), „Państwo i Prawo” $2001, \mathrm{nr} 6$

\section{APPOINTMENT AND REMOVAL OF THE PRESIDENT OF THE POLISH BANK OF POLAND IN THE POLISH CONSTITUTION AND LAW ON THE NATIONAL BANK OF POLAND \\ SUMMARY}

In the article issues are addressed concerning the appointment and removal of the President of the National Bank of Poland. This is a question for the body, which in terms of stage III of integration into the Economic and Monetary Union will play a crucial role. In addition, the President of the NBP is the legal person who, under the law is an element in the integration of the various bodies and authorities and entities operating on the wider financial market. Therefore, it is appropriate to take considerations in this regard. Analysis of the Polish regulations contained in the Constitution and the law on NBP made in the article indicates far-reaching problems not only with unintelligible, but indeed with imperfect regulations relating to the appointment and removal of the President of the NBP. The issues selected and discussed should depict the need for revision of the statutory regulations so as to ensure the implementation of this function by the person with the highest competence and experience. In the article proposals have been made to formulate de lege lata and de lege ferenda, showing that the continuation of these provisions can lead to significant problems of interpretation. 